\title{
THE BACTERIA AND PARASITE PATTERNS IN FLIES DO NOT ASSOCIATE WITH THE PREVALENCE OF FLY VECTOR-BORNE DISEASES AT THE DAIRY FARM
}

\author{
Riza Indira Fadillah Zam Zam ${ }^{1}$, Erma Sulistyaningsih ${ }^{2 *}$, Ancah Caesarina Novi Marchianti ${ }^{3}$ \\ ${ }^{1}$ Magister Program of Public Health, University of Jember, East Java, Indonesia, \\ $2^{2 *}$ Department of Parasitology, Faculty of Medicine, University of Jember, \\ ${ }^{3}$ Department of Public Health, Faculty of Medicine, University of Jember \\ 1indira.riza@gmail.com, *2 sulistyaningsih.fk@unej.ac.id, ${ }^{3}$ ancahcaesarina.fk@unej.ac.id \\ *corresponding author: sulistyaningsih.fk @ unej.ac.id
}

\begin{abstract}
The fly is the vector of several intestinal diseases. It can transmit pathogenic agents, including bacteria such as Salmonella, Shigella, Escherichia coli, Staphylococcus, as well as parasites such as Entamoeba histolytica, Balantidium coli and Giardia lamblia. The dairy farm is one of the sites where the flies are commonly found. This study analyzed the association of the bacteria and parasites pattern in flies and the prevalence of fly vector-borne diseases at the dairy farm. The fly samples were collected at the Rembangan Dairy Farm, and the bacteria and parasite were identified at the Laboratory of Microbiology and Parasitology, Faculty of Medicine, University of Jember. The prevalence data of fly vector-borne diseases were collected from the Public Health Centers around the study site as the secondary data. Bacteria identification using selective media found only $E$. coli, but no parasite was observed in the samples. We found diarrhea, typhoid, and dysentery as fly vectorborne diseases. Statistical analysis using chi-square resulted in $\mathrm{p}=0.072$, meaning no significant association of the bacteria and parasites pattern in flies and the prevalence of fly vector-borne diseases at the dairy farm. The use of secondary data for disease prevalence could be a limitation of the study. Further study by directly examines the samples from fly vector-borne diseases is needed to draw a definite conclusion.
\end{abstract}

Keyword: dairy farm, diarrhea, Escherichia coli, fly, fly vector-borne diseases.

\section{Introduction}

The fly has been known as an essential medical insect in the world [1]. It can transport various pathogens from one place to another. Some microorganisms live in the body or attach to the body's surface and remain viable for approximately 35 days [2,3]. Fly can carry pathogenic agents by attaching them to their body, such as mouth, body surface, foot, wings, and other body parts [4]. They play an important role in the transmission of bacteria and parasites and spread many pathogenic agents that can cause several infectious diseases [5]. Fly usually have direct contact with the dirty areas such as sewage, trash, feces, and other objects, making it possible to transport many microorganisms to the human living area and contaminate them [6].

Some pathogens that are mechanically transmitted are Escherichia coli, Shigella, Salmonella, Vibrio cholera, and parasites such as Balantidium coli, Entamoeba histolytica, Giardia lamblia. This is thought to be related to the prevalence and spread of fly vector-borne disease, including intestinal infection, such as diarrhea, dysentery, typhoid, cholera, and specific helminthic infections, eye infection such as trachoma and conjunctivitis, and certain skin infections such as cutaneous diphtheria, some fungal infections, and leprosy) [7]. Some studies reported a significant correlation between the 
prevalence of intestinal diseases and a seasonal increase of fly population in the human living area $[8,9,10]$.

Numerous fly species which are commonly found in the dairy farm are house fly (Musca domestica), stable fly (Stomoxys calcitrans), horn fly (Haematobia irritants), face fly (Musca autumnalis), deer fly (Chrysops sp.), and horse fly (Tabanus sp.) $[11,12]$. Flies are suspected of using specific cues to identify their potential vertebrate host using a combination of visual, thermal, and olfactory senses [13]. Odor plays a critical role in shorter distance orientation and for eventual contact landing [14]. Flies commonly live in dirty places. They like strong-smell things. House flies usually feed and reproduce in feces, manure, carrion, and other decaying organic substances [15]. A dairy farm is a potential place for breeding for flies. This study aimed to analyze the relationship between bacterial and parasites patterns in flies with the prevalence of infectious intestinal diseases in the dairy farm.

\section{Methods}

\section{Study Site and Ethical approval}

This is a cross-sectional study. The study was conducted at the Rembangan Dairy Farm, Jember, Indonesia from May 2019 to March 2020. This research has received ethical approval from the Ethical Committee of Health Research of Faculty of Dentistry, University of Jember, with reference number 632/ UN25.8/ KEPK/ DL/2019.

\section{Collecting Flies and Microbial identification}

The sampling technique was carried out randomly at the study site. The flies were trapped using bait equipped with the jackfruit, which has a strong odor. The trapped flies were put into a sterile tube containing $\mathrm{NaCl} 30 \mathrm{ml}$ and immediately transported to the Laboratory of Microbiology and Parasitology, Faculty of Medicine, University of Jember.

Flies were washed with sterile physiological solution. The solution obtained from the previous step was added with nutrient agar (NA) and incubated for $24-48 \mathrm{hrs}$ at $37 \mathrm{oC}$. The observation was performed every day, and the previous steps were repeated until the bacterial colony was observed. The bacterial identification was performed by several biochemical tests such as Kligler's Iron Agar (KIA), Indole test, Motility-Indole-Ornithine (MIO) medium, Voges Proskauer (VP) test, Methyl Red (MR) test, and Simmon's Citrate Agar (SCA) test, followed by cultured in selective media including Eosin Methylene Blue (EMB), Salmonella-Shigella (SS) Agar, Thiosulfate Citrate Bile Salt Sucrose (TCBS) agar.

And the identification of parasites was conducted by microscopical examination. Collected flies were washed with sterile physiological solution. The solution was centrifuged at $3.000 \mathrm{rpm}$ for 5 minutes. The sediment was put on the glass slide and added with Lugol and covered with the cover glass. The slide was examined under a microscope with the 400x and 1000x magnification for parasite identification.

\section{Prevalence of fly vector-borne diseases}

The prevalence data of fly vector-borne diseases was provided in a cohort method from the primary health centers located around the study site. The data were collected in the period of November-December 2019.

\section{Statistical Analysis}

The correlation of bacteria and parasite in flies was analyzed using the Chi-square test with a significance level of $5 \%$.

\section{Results}

The bacterial identification from flies was performed using several methods. The biochemical test using KIA, Indol, MIO, VP, $\mathrm{MR}$, and citrate test were presented in Table 1.

Further bacterial identification was conducted using several selective media. The culture of samples using selective media found only Escherichia coli, as shown in Figure 1 and Table 2.

Figure 1 showed that the sample produced a complex purple color on the EMB agar, indicating gram-negative bacteria's growth, i.e., Escherichia coli. The culture in SS agar yielded opaque colonies rather than clear colonies, which meant no Shigella spp. on the agar. Furthermore, the SS media selective for Salmonella spp showed no change in the medium-color into black, indicating no growth of Salmonella spp. The 
culture in the TCBS agar yielded green indicated no growth of Vibrio cholera.

Table 2. The bacteria and parasites identification using selective media and microscopic examination

\begin{tabular}{lcc}
\hline $\begin{array}{c}\text { Bacteria/ } \\
\text { Parasite }\end{array}$ & $\begin{array}{c}\text { Agar } \\
\text { Media }\end{array}$ & Result \\
\hline $\begin{array}{l}\text { Escherichia } \\
\text { coli }\end{array}$ & EMB & + \\
\hline Shigella & SS & - \\
\hline Salmonella & SS & - \\
\hline $\begin{array}{l}\text { Vibrio } \\
\text { cholerae }\end{array}$ & TCBS & - \\
\hline E.histolytica & - & - \\
\hline $\begin{array}{l}\text { Balantidium } \\
\text { coli }\end{array}$ & - & - \\
\hline $\begin{array}{l}\text { Giardia } \\
\text { lamblia }\end{array}$ & - & - \\
\hline
\end{tabular}

Note: EMB: Eosin Methylene Blue; SS: Salmonella-Shigella; TCBS: ThiosulfateCitrate-Bile-Sucrose
The prevalence of fly vector-borne diseases from health centers around the dairy farm were presented in table3. The data were collected from November to December 2019. There were three cases of diarrhea, five typhoid cases, 1 case of dysentery, but no cholera case.

Table 3. The prevalence of fly-vector-borne diseases from the Health Centers around the dairy farm

\begin{tabular}{ccccc}
\hline \multicolumn{3}{c}{$\begin{array}{c}\text { Prevalence of infectious diseases } \\
\text { of flies vectors }\end{array}$} & Tot \\
\cline { 1 - 4 } $\begin{array}{c}\text { diarr } \\
\text { hea }\end{array}$ & $\begin{array}{l}\text { typh } \\
\text { oid }\end{array}$ & $\begin{array}{l}\text { dysent } \\
\text { ery }\end{array}$ & $\begin{array}{l}\text { chole } \\
\text { al }\end{array}$ & \\
\hline 3 & 5 & 1 & 0 & 9 \\
\hline
\end{tabular}

The statistical analysis using the Chisquare test revealed no significant correlation between the bacteria and parasites pattern if flies and the prevalence of fly-vector-borne diseases in the dairy farm, with the significance value of p: 0.072 .

Table 1. Bacterial Biochemical Tests on Flies from the Dairy Farms

\begin{tabular}{|c|c|c|c|c|c|c|}
\hline \multirow{2}{*}{ Bacteria } & \multicolumn{6}{|c|}{ Biochemical Test } \\
\hline & $\boldsymbol{K I A}$ & Indol & MIO & $V P$ & $M R$ & Citrate \\
\hline $\begin{array}{l}\text { Eschericia } \\
\text { coli }\end{array}$ & $\begin{array}{l}\text { S: Alk } \\
\text { B:Acid } \\
\mathrm{H}_{2} \mathrm{~S}:- \\
\text { Gas: - }\end{array}$ & - & + & - & + & + \\
\hline Salmonella & $\begin{array}{l}\text { S: Alk } \\
\text { B:Acid } \\
\mathrm{H}_{2} \mathrm{~S}:+ \\
\text { Gas: + }\end{array}$ & + & - & + & - & - \\
\hline Shigella & $\begin{array}{l}\text { S: Alk } \\
\text { B:Acid } \\
\mathrm{H}_{2} \mathrm{~S}:- \\
\text { Gas: - }\end{array}$ & + & + & + & + & - \\
\hline $\begin{array}{l}\text { Vibrio } \\
\text { cholerae }\end{array}$ & $\begin{array}{l}\text { S: Alk } \\
\text { B:Acid } \\
\mathrm{H}_{2} \mathrm{~S}:- \\
\text { Gas: - }\end{array}$ & - & + & + & - & + \\
\hline
\end{tabular}


Note: KIA: Kligler Iron Agar; MIO: motility-indole-ornithine; MR: Methyl Red; VP: Voges Proskauer; $\mathrm{S}$ : slope; B: base; Alk: alkalis/ bases (red); Acid: acidity (yellow); $\mathrm{H}_{2} \mathrm{~S}$ : Hydrogen sulfide production.

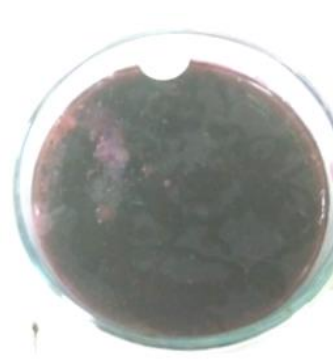

(a)

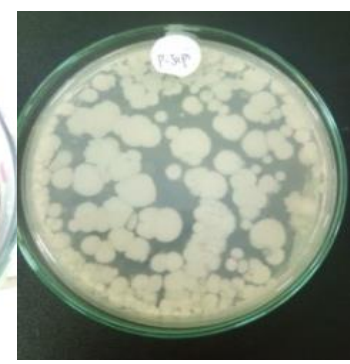

(b)

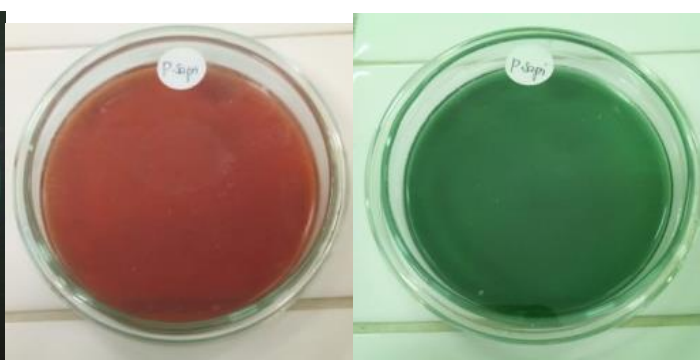

(c)

(d)

Figure 1. The bacterial growth in selective media. (a) The culture in EMB media resulted in a darkpurple color; (b) The culture in Salmonella-Shigella (SS) media revealed opaque colonies that were more like fungal colonies, but no colorless colony which indicated Shigella spp; (c) The culture in SS media showed red color, but no colorless colonies indicated no Shigella spp in the sample; (d) The culture in TCBS media yielded the green color indicated no Vibrio cholera in the sample. 


\section{Discussion}

It is known that fly can act as the mechanical vector of several infectious diseases, especially related to gastrointestinal diseases such as diarrhea, dysentery, and typhoid. Flies like the dirty place and the dairy farm are common areas where flies live. This study analyzed the correlation between bacterial and parasites patterns in flies with the prevalence of infectious intestinal diseases in the dairy farm.

The results of our study demonstrated that only $E$. coli was found in flies and no parasites. The data of fly vector-borne diseases from several health centers located around the Rembangan Dairy Farm, the working areas of Primary Health Center of Arjasa and Patrang, showed the incidence of three diarrhea cases, five typhoid cases, and one dysentery case. We selected the patients who live up to 3- $\mathrm{km}$ far from the Rembangan Dairy Farm. It is intended with the maximum distance of flies to fly and spread the pathogens. Studies showed that 60 $\%$ to $80 \%$ of flies caught within a mile of the release site, but most of the rest, $85 \%$ to $95 \%$ were caught within approximately 2 miles of the release point. Moreover, only a few can fly 5 to 20 miles [16]. Another study reported that the flight range of the houseflies released at the poultry farm was $7 \mathrm{~km}$, whereas the flight range for flies release from a stable farm was 5 $\mathrm{km}$ [17].

Escherichia coli is gram-negative bacteria that can infect the intestine, causing diarrhea and other systems such as the urinary tract and respiratory tract. It is one of the common pathogenic bacteria which can mechanically transmit by flies. The adult house flies can transmit E. coli $\mathrm{O} 157: \mathrm{H} 7$ to cattle, the major reservoir of the human foodborne pathogen [18]. Several studies reported the identified E. coli in a population of houseflies collected from local milk production and manufacturing of handmade Minas cheese [19]. In this study, the five diarrhea cases, possibly due to E. coli infection, coherence with our bacterial identification in our fly samples. Flies in the Dairy Farms perch on cows feces and eat them. Flies eat organic waste, such as animal feces and rotten foodstuffs. Flies can adapt to slums and can coexist with humans. Flies have synanthropic and endophilic properties, which can coexist with humans. Flies are the main vector of foodborne diseases. They can spread various sources of disease. The source of transmission of gram-negative bacteria is thought to come from cow dung on the farm [20].

The finding of five typhoid cases around the Rembangan Dairy farm's location was allegedly not related to bacteria carried by flies from the Dairy Farms. Typhoid can be transmitted from host to host. Humans are a reservoir for Salmonella with disease transmission that occurs via the fecal-oral route [21]. This disease is easily transferred from one person to another with poor personal hygiene and the environment, namely direct transmission. If the bacteria are present in the feces, urine, or vomit, patients can transmit it to others and indirectly through food or drink.

The data analysis resulted in no significant correlation between bacterial and parasites patterns in flies and the prevalence of fly vector-borne diseases around the dairy farm. The result is different from the previous study that reported that house flies cause approximately $37 \%$ of all shigellosis cases in an area in rural Bangladesh $[18,19]$. There are a short-term transmission efficiency and long-term persistence of symptomatic viral infections in confined house fly population. The average rates of disease transmission by flies ranged from $3 \%$ to $24 \%$ and did not vary between the geographical strains originated from different continents. There was a decline in infection level over time in long-term observation, resulting in a $10 \%$ infection rate after passing through 10 filial generations [20]. The population of flies in the Rembangan Dairy Farm is few. That is possibly due to the dairy farms' location in the highland with lower temperatures between $15-20{ }^{\circ} \mathrm{C}$. Fly number in a given area depends on the breeding places, sunshine hours, temperature, and humidity. Fly densities are at the highest at a mean temperature of $20-25{ }^{\circ} \mathrm{C}$. The number decreases at a temperature above and below this range and becomes undetectable at temperatures above $45^{\circ} \mathrm{C}$ and below $10{ }^{\circ} \mathrm{C}$. 
Flies can stay alive in a dormant state at very low temperatures [21]. The flies' activity and the number of flies influence the spread of fly vector-borne diseases around the dairy farm.

\section{Conclusion}

Our study found Escherichia coli bacteria in flies at the Rembangan dairy farm, where the most common fly vector-borne disease was diarrhea and typhoid. The use of secondary data on disease prevalence could be the cause of the study finding that no correlation between the bacterial and parasites pattern in flies and the prevalence of vectorborne diseases. However, the occurrence of diseases and bacterial patterns in flies is interrelated and causes human health problems. Flies are animals that have the most potential mechanical vector of pathogenic agents. Based on this study's results, it is advisable to conduct further research by considering the use of primary data for the number of cases of flies vector-borne disease by performing stool examination in patients to find definite evidence of the cause of diseases.

\section{Acknowledgment}

Thanks to Arjasa and Patrang Primary Health centers which provided the prevalence data of vector-borne diseases.

\section{References}

[1] T.K. Graczyk, R. Knight, R.H. Gilman, and M.R. Cranfield, 2001 "The role of non-biting flies in the epidemiology of human infectious diseases," Microbes. Infect, vol. 3, no. 3, pp. 231-235.

[2] J. Goddard J, 2016, Physician's guide to arthropods of medical importance. CRC Press.

[3] S. Tan, K. Yap, and H. Lee, 1997, "Mechanical transport of rotavirus by the legs and wings of Musca domestica (Diptera: Muscidae)," J. Med. Entomol, vol.34, no. 5, pp. 527-531.

[4] T. Vasan, I. Gilwax, and S. Pandian, 2008, "Vector competence of Musca domestica Linn. with reference to the virulent strains of Salmonella typhi in bus stands and markets at Madurai," Tamil
Nadu. Curr. Biotica, vol. 2, no. 2, pp. 154-160.

[5] B. Hald, H. Skovgård, K. Pedersen, and H. Bunkenborg, 2008, "Influxed insects as vectors for Campylobacter jejuni and Campylobacter coli in Danish broiler houses," Poultry Sci. J, vol. 87, pp. 1428-1434.

[6] T. Chaiwong, T. Srivoramas, P. Sueabsamran, K. Sukontason, M.R. Sanford, and K.L. Sukontason, 2014, "The blow fly, Chrysomya megacephala, and the house fly, Musca domestica, as mechanical vectors of pathogenic bacteria in Northeast Thailand," Trop. Biomed, vol. 31, no. 2, pp. 336-346.

[7] K. Sukontason, M. Bunchoo, B. Khantawa, S. Piangjai, and W. Choochote, 2000, "Musca domestica as a mechanical carrier of bacteria in Chiang Mai, North Thailand," J. Vector Ecol, vol. 5, no. 1, pp. 114-117.

[8] M. Pava-Ripoll, R.E. Pearson, A.K. Miller, B.D. Tall, C.E. Keys, and G.C. Ziobro, 2015, "Ingested Salmonella enterica, Cronobacter sakazakii, Escherichia coli O157: H7, and Listeria monocytogenes: transmission dynamics from adult house flies to their eggs and first filial (F 1) generation adults," BMC Microbiol, vol. 15, no. 1, pp. 150.

[9] A.R. Olsen, and T.S. Hammack, 2000, "Isolation of Salmonella spp. from the housefly, Musca domestica L., and the dump fly, Hydrotaea aenescens (Wiedemann)(Diptera:

Muscidae), at caged-layer houses," J. Food Protect, vol. 63, no. 7, pp. 958960.

[10] S.M. Hosseini, B. Zeyni, S. Rastyani, R. Jafari, F. Shamloo, Z.K. Tabar, et al., 2016, "Presence of virulence factors and antibiotic resistances in Enterococcus $s p$ collected from dairy products and meat," Der Pharmacia Lettre, vol. 8, no. 4, pp. 138-145.

[11] R.E. Williams, 2010, Controlling fies on dairy farms. Livestock \&Poultry. Department of Entomology, Purdue Extension \#E-10-W. Purdue University. 
[12] F. Djenaan, G.J.V. Assa, Z. Poli, and A. Lomboan, 2019, "Jenis dan populasi lalat pada ternak sapi di Desa Tolok, Kecamatan Tompaso, Kabupaten Minahasa," Zootec , vol. 39, no. 1, pp. 5156.

[13] M. Kamut, and T. Jezierski, 2014, "Ecological, behavioral and economic effects of insects on grazing farm animals - a review," Animal Science Paper and Reports, vol. 32, no. 2. Pp. 107-119.

[14] J.J. Zhu, Z. Qing-he, D.B. Taylor, and K.A. Friesen, 2015, "Visual and olfactory enhancement of stable fly trapping, Publications from USDA-ARS/UNL Faculty,pp. 1555.

[15] F. Khamesipour, K.B. Lankarani, B. Honarvar, and T. Emmanuel, 2018, "A systematic review of human pathogens carried by the housefly (Musca domestica L.)," BMC Public Health, vol. 18, pp. 1049.

[16] Entomology of the University of Kentucky, 1997, "How far can house flies fly?," College of Agriculture, Food and Environment. https://entomology.ca.uky.edu/ef506\#: :te $\mathrm{xt}=\mathrm{A} \% 20 \mathrm{few} \% 20 \mathrm{flies} \% 20 \mathrm{have} \% 20 \mathrm{been}, \mathrm{o}$ ne $\% 20$ mile $\% 20$ of $\% 20$ the $\% 20$ source.

[17] W.A.Nazni, H. Luke, W.M. Rozita,A.G. Abdullah, I. Sa'diyah, A.H. Azahari, et al., "Determination of the flight range and dispersal of the house fly, Musca domestica (L.) using mark release recapture technique," Trop Biomed, vol. 22, no. 1, pp. 53-61.

[18] A. Ahmad, T.G. Nagaraja, and L. Zurek L, 2007, "Transmission of Eschericia coli O157:H7 to cattle by house flies," Prev. Vet. Med., vol. 80, no. 1, pp. 74-81.

[19] G. Cardozo G, M. Barbieri, I.V. Dender, F. Trento, and A. Kuyae, 2009, "Musca domestica $\mathrm{L}$ as a vector of pathogenic microorganisms in ultra-filtered fresh Minas cheese," Brazilian J. Food Tech, vol. 12, no. 2, pp. 85-91.

[20] N. Abbas, H.A.A. Khan, and S.A. Shad, 2014, "Resistance of the house fly Musca domestica (Diptera: Muscidae) to lambdacyhalothrin: mode of inheritance, realized heritability, and cross-resistance to other insecticides," Ecotoxicol, vol. 23, no. 5, pp. 791-801.

[21] A. Martha, 2019, "Epidemiologi, Manifestasi Klinis, dan Penatalaksanaan Demam Tifoid. J. Nut. Health, vol. 7, no. 2, pp. 32-38.

[22] T.H. Farag, A.S. Faruque, Y. Wu, S.K. Das, A. Hossain, S. Ahmed S, et al., 2013, "Housefly population density correlates with shigellosis among children in Mirzapur, Bangladesh: a time series analysis," PLOS Neglect. Trop. Dis.

https://doi.org/10.1371/journal.pntd.0002 280

[23] O.S. Levive, and M.M. Levine, 1991, "Houseflies (Musca domestica) as mechanical vectors of shigellosis," Rev. Infect. Dis., vol. 13, no. 4, pp. 688-696.

[24] V. Lietze, C.J. Geden, M. Doyle, and D.G. Boucias, 2012, "Disease dynamics and persistence of Musca domestica salivary gland hypertrophy virus infections in laboratory hous fly (Musca domestica) populations," Appl. Environ. Microbiol., vol. 78, no. 2, pp. 311-317.

[25] J. Keiding, 1986, "The housefly-biology and control. Training and information guide (advanced level)," Geneva, WHO. unpublished document WHO/VBC/86.937. 